\title{
Early-Stage Thinning for the Restoration of Young Redwood-Douglas-Fir Forests in Northern Coastal California, USA
}

\author{
Jesse F. Plummer, ${ }^{1}$ Christopher R. Keyes, ${ }^{2}$ and J. Morgan Varner ${ }^{3}$ \\ ${ }^{1}$ USDA Forest Service, Fremont/Winema National Forests, Supervisor's Office, 1301 South G Street, Lakeview, OR 97630, USA \\ ${ }^{2}$ Department of Forest Management, University of Montana, 32 Campus Drive, Missoula, MT 59812, USA \\ ${ }^{3}$ Department of Forestry and Wildland Resources, Humboldt State University, Harpst Street, Arcata, CA 95521-8299, USA
}

Correspondence should be addressed to Christopher R. Keyes, christopher.keyes@umontana.edu

Received 17 October 2011; Accepted 23 November 2011

Academic Editor: A. Bortolus

Copyright (C) 2012 Jesse F. Plummer et al. This is an open access article distributed under the Creative Commons Attribution License, which permits unrestricted use, distribution, and reproduction in any medium, provided the original work is properly cited.

\begin{abstract}
Among forested parks and reserves of the Pacific Coast of the United States, the restoration of late-successional conditions to second-growth stands is a management priority. Some traditional silvicultural treatments may help achieve this objective. We evaluated early-stage thinning as a restoration treatment to facilitate the growth and development of young (33- to 45-year old), homogeneous, and second-growth stands of coast redwood (Sequoia sempervirens) and Douglas-fir (Pseudotsuga menziesii). Targeting both stand-level responses and dominant (focal) tree responses for analysis, we compared structural attributes of adjacent thinned and unthinned stands, 12-17 years after thinning. Thinned stands displayed enhanced metrics of tree vigor, growth, and mechanical stability, thereby improving response to future restoration treatments and broadening the range of potential stand conditions. We conclude that early-stage thinning has been successful as a preliminary restoration treatment because it accomplished many initial goals of forest restoration, while retaining sufficient tree numbers to buffer against possible attrition from future disturbances.
\end{abstract}

\section{Introduction}

Throughout the range of coast redwood (Sequoia sempervirens), facilitating the acquisition of late-successional forest structures and compositions in second-growth forests has become a primary management objective. It is estimated that less than 10 percent of original old-growth redwood forests remain [1], the majority of which have been conserved in parks and reserves. In order to continue promoting the extent of late-successional habitat on a landscape scale, focus has switched to the area's second-growth forests [2]. In many cases, ecological restoration of these former commercial timberlands may require some forms of silvicultural treatment [3].

In young stands acquired for such conservation purposes, early-stage thinning has been proposed as a potential restoration treatment. Some stand responses to early-stage thinning have been documented in pure stands of coast redwood [4-6] and pure stands of Douglas-fir (Pseudotsuga menziesii)
[7-9]. However, analysis of early-stage thinning's effects on the region's more ubiquitous mixed redwood-Douglas-fir stands is lacking. Similar to O'Hara et al. [10], we use the term "early-stage thinning" to describe a forest restoration technique whose primary purpose is shifting composition imbalances and reducing stand densities in order to accelerate growth in young second-growth stands, with the ultimate long-term objective of acquiring old-growth forest characteristics. This distinguishes early-stage thinning from similar treatments applied to commercial timber production (precommercial thinning), and from other thinning treatments that are often applied to older stands in later stages of structural development.

An excellent example of former redwood timberland now managed with restoration goals is the California Department of Parks and Recreation's Mill Creek Property in northern coastal California (Figure 1). Acquired in 2002, the management directive of this park unit (an addition to 


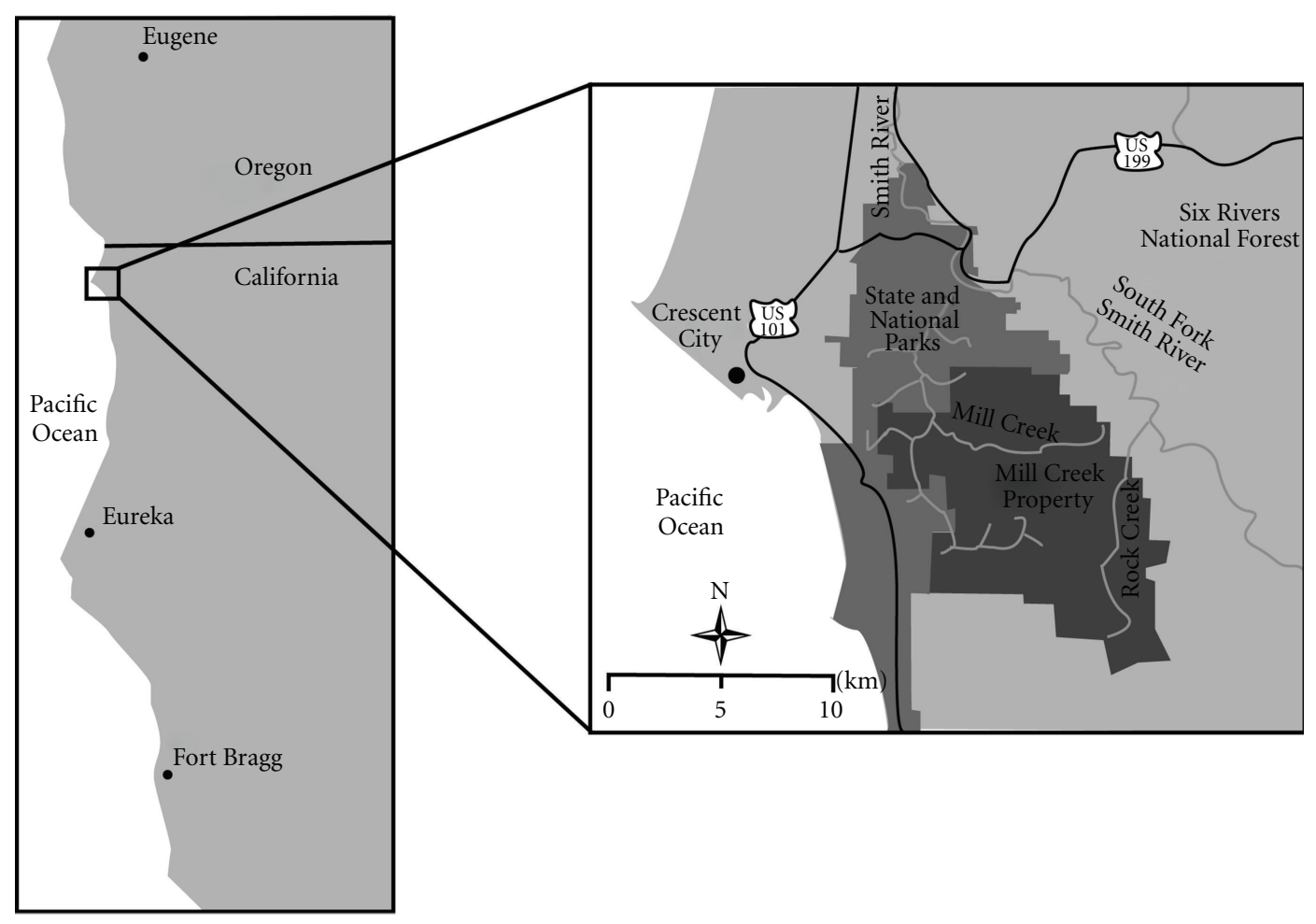

FIGURE 1: Mill Creek Property (study site) in northern California, USA.

Del Norte Coast Redwoods State Park) is to "restore latesuccessional forest conditions and the associated natural functions for the benefit of the areas' fish and wildlife" [2]. The Mill Creek Property contains 10,120 ha of forestlands, the majority of which is comprised of young (33 to 45 years old), even-aged mixed stands of coast redwood and Douglas-fir, which were established following clearcutting of the original redwood-dominated forest. Consistent with its planned use as commercial timberland, the previous owner had performed early-stage (or precommercial) thinning on approximately 1,012 ha. The thinning was performed in stands 9 to 34 -year old at approximately $4.25 \mathrm{~m}$ spacing, with no particular species preference.

This study was conducted to (a) determine the existing condition of young coast redwood-Douglas-fir stands at the Mill Creek Property and (b) document the effects of early-stage thinning on tree and stand structural attributes of special concern to forest restoration. We hypothesized that thinning would enhance metrics of tree size, vigor, growth, stability, and branch diameter. Most restoration activities in the redwood region have focused on older stands, but studies elsewhere in the Pacific Northwest forests have demonstrated that early-stage thinning enhances tree growth and vigor, expediting the growth of large trees, height differentiation, and development of late-successional forest structure $[3,11]$. Early-stage thinning has also been demonstrated to improve tree resistance to wind and snow damage $[9,12,13]$.

For this analysis we employed a novel assessment focused on trees occupying upper canopy positions (analogous to crop trees in timber management), hereafter referred to as "focal trees." Focal trees were targeted because, in dense young stands managed with long-term goals (as the Mill Creek Property), only a subset of dominant upper canopy trees are of primary interest. Old-growth redwood forests canopies typically consist of 50-100 tree ha- $\mathrm{t}^{-1}$. In secondgrowth stands, most trees of subordinate canopy positions will not survive the stem exclusion phase [14] and are essentially ephemeral. Traditional analyses of stand averages underestimate upper canopy tree responses because trees of subordinate canopy positions are included [15]. In response to this concern, previous studies avoided the influence of suppressed trees on stand averages by constraining evaluations to the largest 100 to 250 trees ha $^{-1}$ (e.g., $[7,9,12,15]$ ). We used a similar method, refining the selection of focal trees based on canopy position.

\section{Methods}

2.1. Study Area. The Mill Creek Property is located in the Coast Range of northwestern California, USA, $10 \mathrm{~km}$ southeast of Crescent City $\left(41.7363^{\circ} \mathrm{N}, 124.0914^{\circ} \mathrm{W}\right)$ and $5 \mathrm{~km}$ from the coast. The climate is dominated by Mediterranean and maritime influences; temperatures are moderated and rarely drop below freezing, averaging $4.2^{\circ}$ to $19.8^{\circ} \mathrm{C}$, and precipitation occurs mostly during winter as rain, annually averaging $180 \mathrm{~cm} \mathrm{[16].} \mathrm{Fog} \mathrm{is} \mathrm{common} \mathrm{year} \mathrm{round.}$

The topography of the Mill Creek Property consists of steep river-cut canyons. Soils in sample sites are dominated 
by gravelly clay loam Ultisols of the Coppercreek, Tectah, Lackscreek, and Slidecreek Series [17]. Elevation of sample sites range from $150 \mathrm{~m}$ to $410 \mathrm{~m}$ a.s.l. Site productivity is class I for Douglas-fir (43-50 m at 50 years; [18]), and class I and II for redwood (36-50 $\mathrm{m}$ at 50 years; [19]).

At the time of this study, vegetation of the Mill Creek Property was dominated by mixed coast redwood-Douglasfir stands, with minor components of Alnus rubra (red alder), Lithocarpus densiflorus (tanoak), Picea sitchensis (Sitka spruce), Abies grandis (grand fir), Tsuga heterophylla (western hemlock), Thuja plicata (western redcedar), Chamaecyparis lawsoniana (Port-Orford-cedar), and Acer macrophyllum (bigleaf maple). The most common understory and shrub species were Vaccinium ovatum (evergreen huckleberry), Gaultheria shallon (salal), Rhododendron macrophyllum (Pacific rhododendron), Ceanothus thyrsiflorus (blueblossom), and Polystichum munitum (sword fern).

In order to quantify thinning effect, we required adjacent stands of identical condition except treatment history (thinning). Five even-aged coast redwood-Douglas-fir areas in the Mill Creek Property were identified that met the criteria, each including a thinned stand and an adjacent, paired unthinned stand. In intensively managed commercial timberlands where precommercial thinning is a standard treatment, finding thinned/unthinned pairs is a challenge; this proved to be true at Mill Creek as well and limited the study's sample size to the five pairs. A number of criteria were enforced to ensure that stand pairs were comparable. To minimize variation in microclimate, stand pairs were located less than $100 \mathrm{~m}$ apart. To ensure stand pairs developed under the same weather conditions, stand pairs did not differ in age more than 3 years. In order to isolate redwood-Douglas-fir dynamics, study sites were selected in areas where other tree species were not present. Four of the stand pairs ranged in age from 33 to 37 years (originated from 1970 to 1974); the fifth pair was 45 years old (originated 1962). Thinned areas had been treated 12 to 17 years prior to the study.

To isolate treatment effects, measurement plots were located in at the center of the most visually representative portion of each stand, which best typified the surrounding stand structure (stem density, species composition, and age) and microsite (apparently homogeneous soil, site quality, aspect, slope, hydrology, and buffered from roads and thinned areas). Sprouts and seedlings were both included in the sample when sprout clump density was not uncharacteristic of the surrounding stand; however, dense redwood sprout clumps were not included in the sample, in order to eliminate spatial effects. The lower stem density of thinned stands required a larger fixed-radius circular plot to capture approximately the same number of trees (sensu [20]); therefore, thinned plots were $400 \mathrm{~m}^{2}$ (0.04 ha), and unthinned plots were $250 \mathrm{~m}^{2}$ ( $0.025 \mathrm{ha}$ ).

To quantify tree-level responses among the most competitive individuals, we also analyzed a subset of the largest trees in each stand (focal trees) within a 0.2 ha circular plot centered on the sample plot centers. The ten most dominant trees from the upper canopy-five each of Douglas-fir and redwood-were selected. In order to isolate thinning effect, selection preference was given to trees free of bole defects and excessively large branches (indicating the influence of adjacent persistent gaps on growth). Analyzing this focal tree subset enabled us to avoid the influence of suppressed trees on stand averages, a strategy consistent with previous studies that focused on crop tree development (e.g., $[7,12,15])$.

2.2. Tree Measurements. We recorded species, dbh, and height of trees $>10.16 \mathrm{~cm}$ dbh (diameter at breast height: $1.37 \mathrm{~m}$ above ground) in sample plots. Focal trees were felled in order to accurately measure tree height, diameter inside bark at breast height (dib), age, crown base height, 10-year radial growth increment at breast height, and diameter of the largest three branches. Crown base height was recorded as the lower limit of the functional live crown, with small or isolated branches below the main crown disregarded. The 10year radial growth increments and live crown ratios of focal trees were measured as indicators of immediate past growth and current vigor.

Because large branches are important wildlife habitat and epiphyte substrate [21-23] and previous studies reported increases in branch diameters due to early thinning [24, 25], diameter of the largest three branches of each focal tree was measured to determine if thinning increased the mean maximum branch diameter. The number of branches measured on each tree was within the range of previous studies' sampling intensity, which ranged from measuring the thickest branch on each tree [26] to every branch on each tree $[22,27]$. Selection of the largest three branches was confined to the functional live crown, and branch caliper was measured $10 \mathrm{~cm}$ from the main stem.

The ratio of tree height to diameter at breast height (h:d; same units) is a metric that is frequently employed to assess a tree's mechanical resistance to stem breakage [28]. Lower h:d ratios are strongly and negatively associated with increased mechanical resistance to stem breakage typically caused by snow, ice, and wind, for conifer species [12]. Trees with h:d ratios lower than approximately $80: 1$ have consistently proven resistant to windthrow and windsnap, whereas trees with ratios above that threshold are substantially more susceptible to damage $[12,29]$. Because bark thickness differed substantially between redwood and Douglas-fir, and bark contributes little to the mechanical strength of the tree stem, we employed a modified h:d ratio using the within-bark breast-height diameter (dib, h:dib) instead of dbh (outside bark), in order to isolate differences in each species' response to thinning. This helped us avoid artificially inflating redwood's relative improvement in stability due to its relatively thicker bark.

2.3. Data Analyses. Stand level responses to thinning were calculated using all trees in each sample plot. Tree level responses to thinning were measured using only focal trees in the larger plots. Data from thinned stands and unthinned stands were compared via two-sample $t$-tests, utilizing both stand characteristics [density, basal area, stand density index (SDI), and quadratic mean diameter (QMD)] and individual focal tree characteristics (dib, 10-year radial growth, live crown ratio, h:dib ratio, and mean maximum branch caliper). Diameter and height distributions were 
TABLE 1: Mean tree density ( stems ha $\left.{ }^{-1}\right)$, basal area $\left(\mathrm{m}^{2} \mathrm{ha}^{-1}\right)$, quadratic mean diameter (QMD), and stand density index (SDI) of thinned and unthinned coast redwood-Douglas-fir stands at the Mill Creek Property. Significant differences $\left(^{*}\right)$ were determined via two-sample $t$-tests at $\alpha=0.05$.

\begin{tabular}{|c|c|c|c|c|c|c|}
\hline & \multicolumn{3}{|c|}{ Thinned } & \multicolumn{3}{|c|}{ Unthinned } \\
\hline & Douglas-fir & Redwood & Overall & Douglas-fir & Redwood & Overall \\
\hline Density (trees ha ${ }^{-1}$ ) & $320(61 \%)$ & $205(39 \%)$ & $525^{*}$ & $664(58 \%)$ & $480(42 \%)$ & 1144 \\
\hline Basal area $\left(\mathrm{m}^{2} \mathrm{ha}^{-1}\right)$ & $31.7(52 \%)$ & $29.0(48 \%)$ & 60.7 & $41.1(55 \%)$ & $33.8(45 \%)$ & 75.0 \\
\hline QMD (cm) & $36.1^{*}$ & $43.2^{*}$ & $39.7^{*}$ & 27.5 & 27.6 & 27.5 \\
\hline SDI & & & $383^{*}$ & & & 574 \\
\hline
\end{tabular}

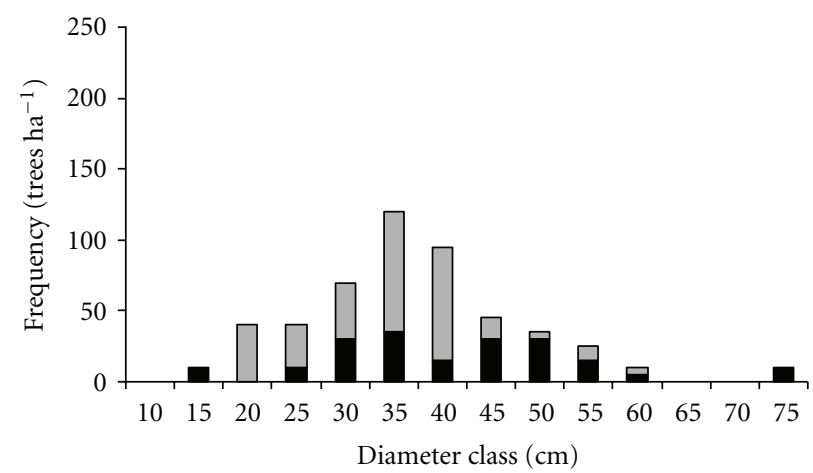

(a)

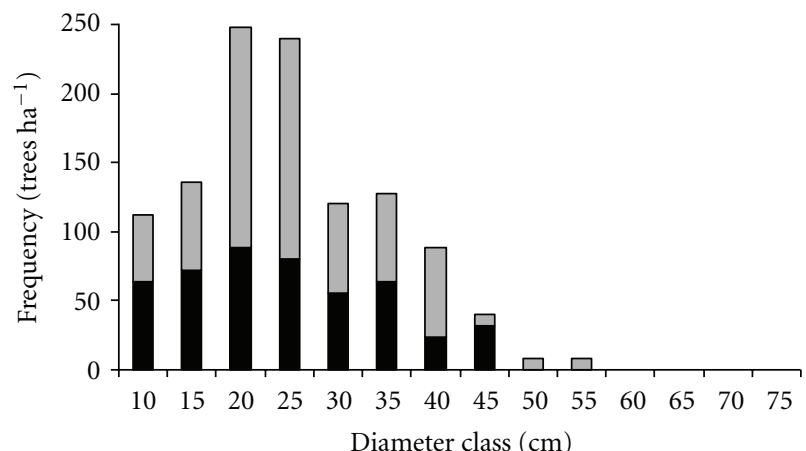

$\square$ Douglas-fir

- Redwood

Figure 2: Collective diameter distributions of thinned stands (a) and unthinned stands (b) at the Mill Creek Property.

calculated with $5 \mathrm{~cm}$ diameter classes and $2 \mathrm{~m}$ height classes. From stand data we calculated stand density index (SDI) to compare the level of competition between thinned and unthinned stands. SDI is a common diagnostic tool for assessing degrees of stand-level competition $[30,31]$ and is founded upon size-density relationships [32]. For all statistical analyses, significance was determined at $\alpha=$ 0.05 . Each dataset was evaluated for its conformity to the assumptions of these analyses; assumptions of normality and equal variances were not rejected (all $P>0.05$ ) for any datasets used in this study.

\section{Results}

3.1. Stand Level Responses. Unthinned stands averaged 1,144 trees $\mathrm{ha}^{-1}$, and thinned stands contained 54\% fewer trees $(P<0.003$, Table 1$)$. The level of competition as assessed using SDI was 50\% higher in unthinned stands (574) than thinned stands $(383)(P<0.02)$. Thinning did not affect species composition by either density (trees ha ${ }^{-1}$ ) and basal area $\left(\mathrm{m}^{2} \mathrm{ha}^{-1}\right)(P>0.05)$; thinned and unthinned stands were both dominated by Douglas-fir ( $60 \%$ of density and $54 \%$ of basal area).

Thinning substantially enhanced diameter growth. Quadratic mean diameter was $44 \%$ greater in thinned stands than in unthinned stands $(P<0.001)$, and redwood QMD was more strongly affected (57\% improvement) than Douglas-fir (31\% improvement). The diameter distributions
(Figure 2) revealed that thinned stands contained 123\% more trees exceeding $40 \mathrm{~cm}$ dbh; within those larger diameter classes, the proportion of redwood was $26 \%$ greater than unthinned stands. The reduction in stand density from thinning is illustrated by the sharp reduction in density in the smaller diameter classes $(<25 \mathrm{~cm}$, Figure 2$)$. The height distribution of thinned and unthinned stands shows the removal of stems occupying shorter height classes $(<26 \mathrm{~m}$, Figure 3) due to thinning. Thinning did not enhance canopy height, but it did result in thinned stands containing $22 \%$ more trees exceeding than $32 \mathrm{~m}$ than unthinned stands (Figure 3).

3.2. Focal Tree Responses. Thinning effects were observed for all measures of focal tree responses, and redwood's responses exceeded Douglas-fir's in every measure. Focal tree dib was $35 \%$ larger in thinned stands $(39.1 \mathrm{~cm})$ than unthinned stands $(29.0 \mathrm{~cm}, P<0.001$, Figure 4$)$. The dib difference was stronger for redwood ( $43 \%$ increase) than Douglasfir $(28 \%$ increase). Focal trees in thinned stands had $70 \%$ greater 10-year radial growth increment than unthinned stands $(P<0.001$, Figure 5$)$. Redwood was more positively affected by thinning, experiencing $99 \%$ greater radial growth over unthinned stands, whereas Douglas-fir radial growth was $45 \%$ greater. Live crown ratios in thinned stands were $27 \%$ greater than unthinned stands, increasing from a mean live crown ratio of $39 \%$ to $50 \%(P<0.001$, Figure 6$)$. Redwood's live crown ratio was $36 \%$ greater, and the crown 


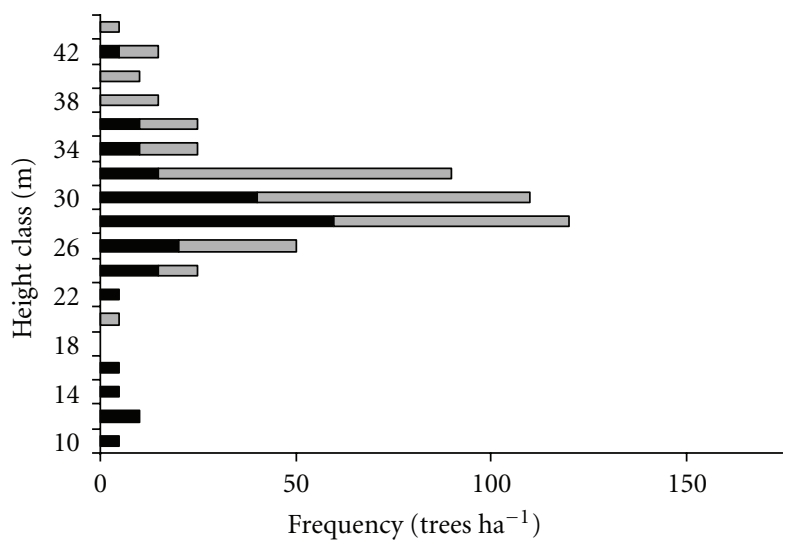

(a)

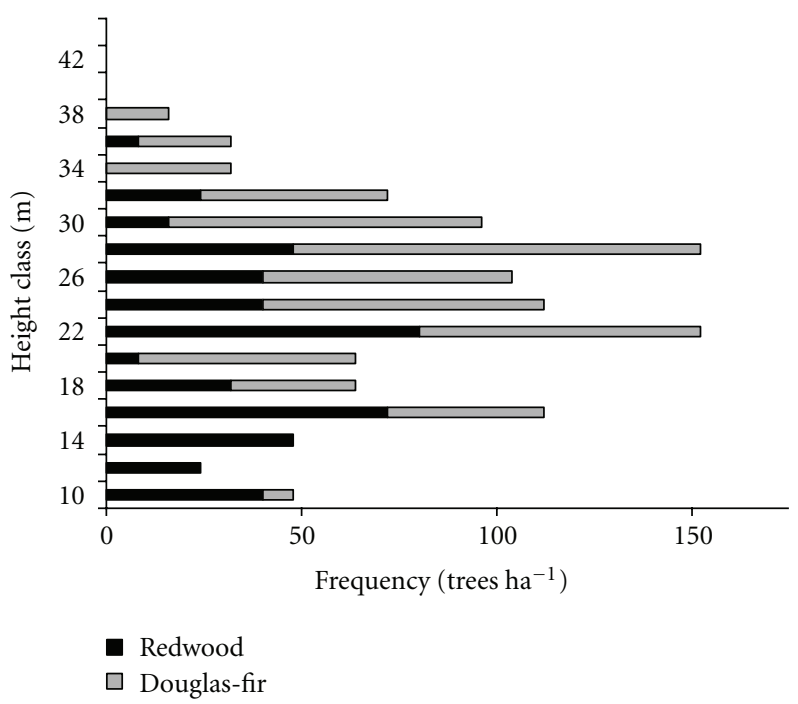

(b)

Figure 3: Collective height distributions of thinned stands (a) and unthinned stands (b) at the Mill Creek Property.

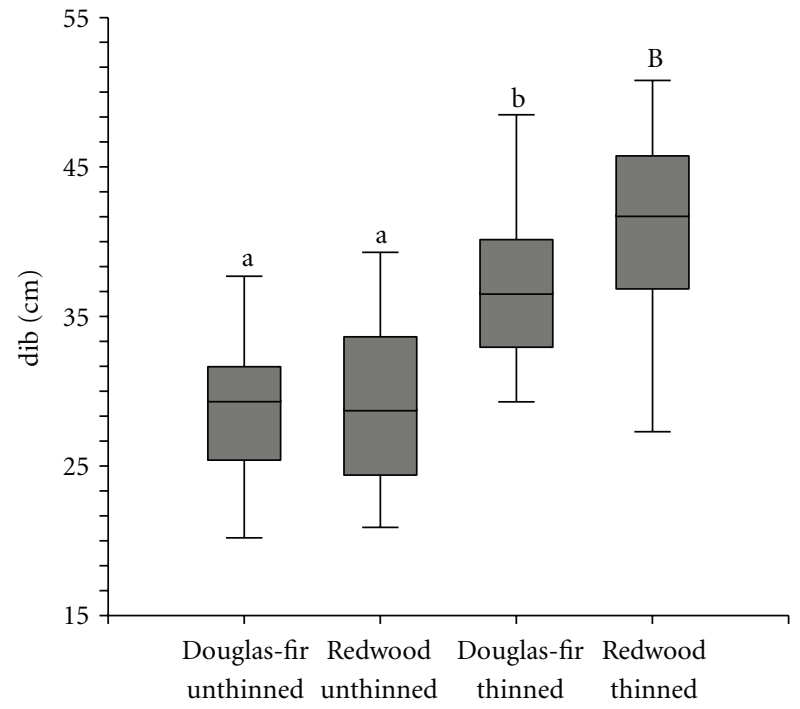

FIgURE 4: Diameter inside bark at breast height (dib) of focal trees in thinned and unthinned stands at the Mill Creek Property. Letters and case indicate statistically significant differences between treatment and within treatment, respectively $(P<0.05)$. Box denotes the interquartile range (IQR); line within box denotes median; whiskers denote observations within $1.5 \times \mathrm{IQR}$.

ratio of Douglas-fir trees was 19\% greater in thinned stands. Mean maximum branch diameter was 35\% larger in thinned stands $(39.4 \mathrm{~mm})$ than unthinned stands $(29.1 \mathrm{~mm}, P<$ 0.001). Although redwood exhibited a greater branch size difference between thinned and unthinned stands (redwood $55 \%$, Douglas-fir 20\%), Douglas-fir possessed larger mean maximum branch calipers in both thinned and unthinned stands $(P<0.008$, Figure 7$)$. The mean h:dib ratio of focal trees was $18 \%$ lower in thinned stands (87.5) than unthinned stands (106.2, $P<0.001$, Figure 7). The h:dib ratio of redwood was $26 \%$ lower and Douglas-fir $11 \%$ lower in thinned stands than unthinned stands.

\section{Discussion}

To restore redwood dominance and historic stand structures to second-growth forests, restoration treatments may be necessary to ameliorate artifacts of timber management, including unnaturally high stand densities and altered species compositions [2,33]. The historic stand conditions surveyed in the 1969 forest inventories of uncut timberland in the Mill Creek Property, where old-growth forest conditions still existed, revealed low stand densities, averaging only 79 trees ha ${ }^{-1}$, with $82 \%$ of the volume comprised of redwood and only $12 \%$ Douglas-fir [34]. Existing stump evidence and surrounding undisturbed stands at Mill Creek seem to validate those data.

In this study, redwood was underrepresented in both thinned and unthinned stands compared to historic conditions. This divergence from historic composition persists in thinned stands because the thinning conducted at Mill Creek was designed for volume production and did not attempt to alter species composition. Although redwood is still compositionally under-represented, this analysis reveals that redwood's competitive potential for future dominance was higher in thinned stands because of redwood's relatively greater responses to thinning relative to Douglas-fir. Redwood's improved response to thinning positions the species for gains in proportional composition, as stand development progresses. An opportunity exists to further increase the potential for redwood dominance, by preferentially retaining redwood and preferentially removing Douglas-fir preferentially removed in later thinnings.

The densities of stems (trees ha ${ }^{-1}$ ) in both thinned and unthinned stands were high relative to old-growth stands. Studies in the redwood region [35-37] have documented 


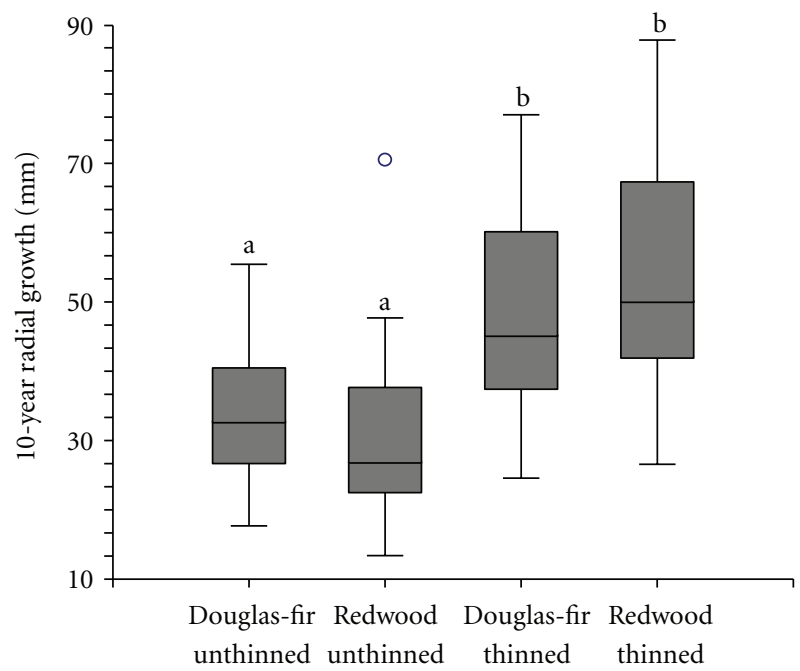

(a)

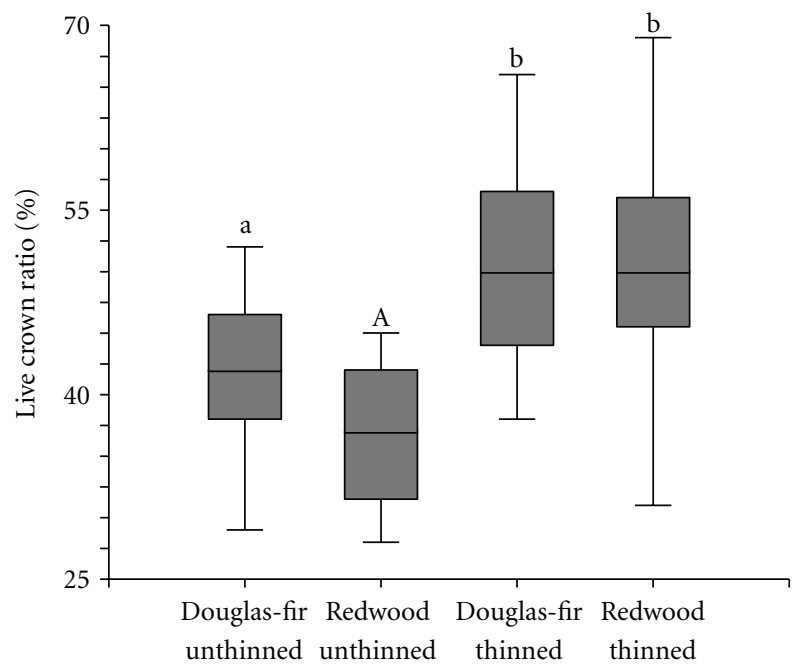

(b)

FIGURE 5: 10-year radial growth (a) and live crown ratios (b) of focal trees within thinned and unthinned stands at the Mill Creek Property. Letters and case indicate statistically significant mean differences between treatment and within treatment, respectively $(P<0.05)$. Box denotes the interquartile range (IQR); line within box denotes median; whiskers denote observations within $1.5 \times I Q R$.

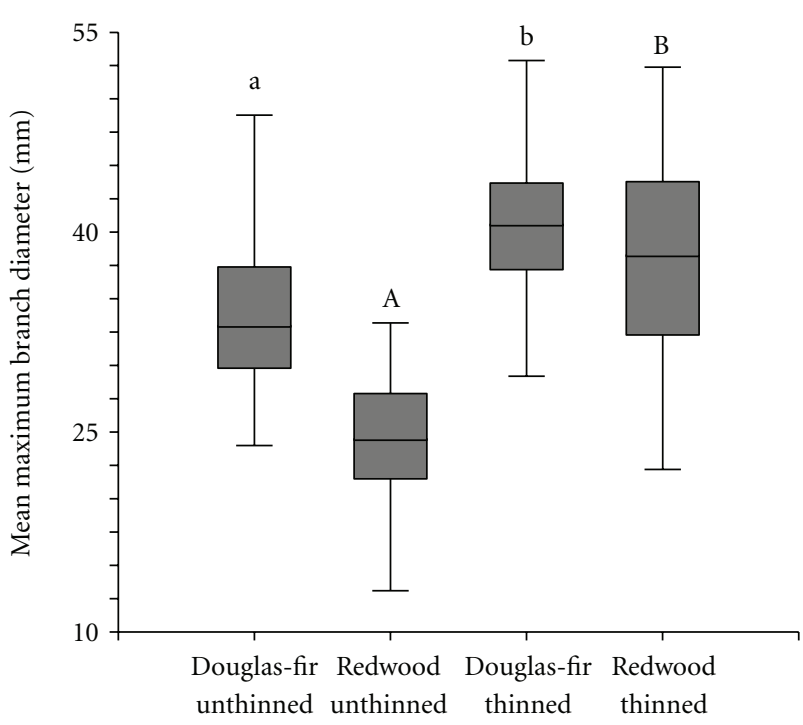

Figure 6: Mean maximum branch diameter $(\mathrm{mm})$ of focal trees in thinned and unthinned stands at the Mill Creek Property. Letters and case indicate statistically significant differences between treatment and within treatment, respectively $(P<0.05)$. Box denotes the interquartile range (IQR); line within box denotes median; whiskers denote observations within $1.5 \times \mathrm{IQR}$.

old-growth stand densities averaging fewer than 200 trees $\mathrm{ha}^{-1}$, much lower those we found in either thinned (525 trees/ha) or unthinned (1,144 trees/ha) stands at Mill Creek (Table 1). Sprouting of redwood and artificial regeneration of Douglas-fir contributed to high tree densities.

Declines in vigor (measured using live crown ratio) and growth (measured using the 10-year radial growth increment) negatively affect a stand's ability to respond to future thinnings and compromise a stand's potential developmental pathways [13]. In this study, thinning resulted in $27 \%$ greater live crowns (Figure 5), apparently due to slowed crown recession which permitted trees to accrete crown length. The greater live crowns resulted in improvment in tree growth and vigor, as exhibited by the $70 \%$ greater 10 -year radial growth increment (Figure 5). Slower diameter growth increases the amount of time required for trees to reach historic proportions [3].

Restoration of coast redwood-Douglas-fir stands would be incomplete if it did not promote habitat for special interest plant and animal species. In the redwood region, large branches are considered critical habitat for plant and animal species $[21,23,38]$. In this study, mean maximum branch diameter of thinned stands $(39.1 \mathrm{~mm})$ was significantly larger than unthinned stands $(29.0 \mathrm{~mm})$, and mean maximum branch diameter of Douglas-fir was larger than redwood (Figure 6).

In regions where wind- and snow-caused tree mortality are common, differences in stability between trees competing for canopy dominance have implications for long-term species composition. Wind storms are a significant source of stand-level disturbance in forests of the Pacific coastal United States [12, 28, 39]. For conifers, damage from snow loads, ice storms, and windsnap is largely a function of h:d ratio [40]. Focal trees in this study possessed lower h:dib ratios as a result of thinning, indicating their relatively greater resistance to wind and snow damage than unthinned stands [12]. Wind and snow damage in mature trees frequently creates complex canopy architecture (e.g., reiterated tops and large branches) that can be desirable plant and animal habitat features $[22,38,41]$, but widespread stem breakage in young dominant trees impedes stand development and can render restoration treatments counterproductive.

In this study, redwood and Douglas-fir focal trees had similar h:dib ratios in unthinned stands, but redwood responded 


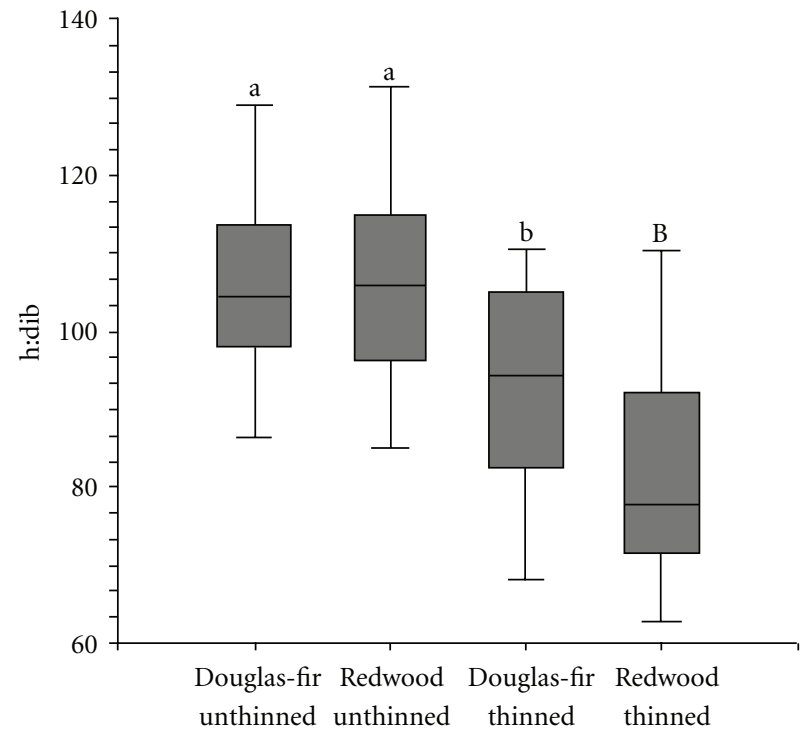

Figure 7: Height-to-diameter inside bark ratio (h:dib) of focal trees in thinned and unthinned stands at the Mill Creek Property. Letters and case indicate statistically significant differences between treatment and within treatment, respectively $(P<0.05)$. Box denotes the interquartile range (IQR); line within box denotes median; whiskers denote observations within $1.5 \times \mathrm{IQR}$.

more positively to thinning than Douglas-fir, improving its h:dib by $26 \%$. In thinned stands, the h:dib ratio of redwood was $14 \%$ lower than Douglas-fir, indicating Douglas-fir's relatively greater susceptibility to wind damage. We suggest employing the h:dib ratio of focal trees as a method to assess and compare the stability of conifer species with differing bark thickness and to provide insight on future stand development and vulnerabilities of each species. Because focal trees in unthinned stands of this study exhibited unstable h:dib ratios, future thinning of these stands should be conducted, in a conservative manner to limit wind exposure $[12,29,42]$.

The form of early-stage thinning described here yielded restoration benefits that can be distinguished from traditional low thinning [43], variable-density thinning as typically employed in older stands [44, 45], or even earlystage variable-density thinning that seeks to establish low stand density and substantial canopy gaps in a single-phase restoration strategy $[10,46]$. In contrast to those strategies, early-stage thinning, as part of a multiphase restoration strategy, represents a restoration compromise between efficiency and risk; it provides limited release from competition while retaining sufficient density to buffer mortality and limit wind exposure.

In a recent study focused on variable-density thinning's influence on wind damage, Roberts and others [42] recommended that stands with high stem densities and exhibiting unstable h:d ratios be treated with a light uniform thinning prior to prescribing variable-density thinning. Applied in that patient restoration strategy, early-stage thinning would promote a population of more stable and vigorous trees around which complex restoration treatments can subsequently be designed at a time more appropriate in later stages of stand development. We suggest that managers of young mixed redwood-Douglas-fir stands consider, among other options, a two-stage restoration strategy that utilizes earlystage thinning as an initial treatment (focused on species composition and tree-level growth, vigor, and stability), to be followed later by variable-density thinning that focuses on the promotion of spatial heterogeneity and the cultivation of structural elements such as coarse woody debris and snags.

\section{Acknowledgments}

The authors thank L. Fox, J. Peach, K. Curtis, P. Clusener, M. Deshazo, and J. Kane for field assistance and Save-theRedwoods League for financial support. The study was made possible in part by the Applied Forest Management Program at the University of Montana, a research and demonstration unit of the Montana Forest and Conservation Experiment Station.

\section{References}

[1] L. Fox, "A classification, map and volume estimate for the coast redwood forest in California," Final Report, Interagency Agreement 8CA52849, The Forest and Rangeland Resources Assessment Program, California Department of Forestry and Fire Protection, Sacramento, Calif, USA, 1989.

[2] D. Porter, V. Gizinski, R. Hartley, and S. H. Kramer, "Restoring complexity to industrially managed timerlands: the Mill Creek interim management recommendations and early restoration thinning treatments," in Proceedings of the Redwood Region Forest Science Symposium: What Does the Future Hold? R. B. Standiford, G. A. Giusti, Y. Valachovic, W. J. Zielinski, and M. J. Furniss, Eds., USDA Forest Service General Technical Report PSW-GTR-194, pp. 283-294, Pacific Southwest Research Station, Albany, Calif, USA, 2007.

[3] R. T. Busing and S. L. Garman, "Promoting old-growth characteristics and long-term wood production in Douglas-fir forests," Forest Ecology and Management, vol. 160, no. 1-3, pp. 161-175, 2002.

[4] W. W. Oliver, J. L. Lindquist, and R. O. Strothmann, "Younggrowth redwood stands respond well to various thinning intensities," Western Journal of Applied Forestry, vol. 9, pp. 106112,1994

[5] J. L. Lindquist, "Precommercial stocking control of coast redwood: a seventeen-year status report (1981-1998)," California Forestry Report 2, California Department of Forestry and Fire Protection, 2004.

[6] J. L. Lindquist, "The Whiskey Springs redwood commercial thinning study: a 29-year status report (1970 to 1999)," in Proceedings of the Redwood Region Forest Science Symposium: What Does the Future Hold? R. B. Standiford, G. A. Giusti, Y. Valachovic, W. J. Zielinski, and M. J. Furniss, Eds., USDA Forest Service General Technical Report PSW-GTR-194, pp. 305-316, Pacific Southwest Research Station, Albany, Calif, USA, 2007.

[7] R. O. Curtis and D. L. Reukema, "Crown development and site estimates in a Douglas-fir plantation spacing test," Forest Science, vol. 16, pp. 287-301, 1970.

[8] D. L. Reukema, "Guidelines for precommercial thinning of Douglas-fir," USDA Forest Service General Technical Report PNW-GTR-30, 1975. 
[9] D. L. Reukema, "Fifty-year development of Douglas-fir stands planted at various spacings," USDA Forest Service Research Paper PNW-RP-253, 1979.

[10] K. L. O’Hara, J. C. B. Nesmith, L. Leonard, and D. J. Porter, "Restoration of old forest features in coast redwood forests using early-stage variable-density thinning," Restoration Ecology, vol. 18, no. 1, pp. 125-135, 2010.

[11] J. D. Bailey and J. C. Tappeiner, "Effects of thinning on structural development in 40- to 100-year old Douglas-fir stands in western Oregon," Forest Ecology and Management, vol. 108, no. 1-2, pp. 99-113, 1998.

[12] J. S. Wilson and C. D. Oliver, "Stability and density management in Douglas-fir plantations," Canadian Journal of Forest Research, vol. 30, no. 6, pp. 910-920, 2000.

[13] J. S. Wilson and P. J. Baker, "Flexibility in forest management: managing uncertainty in Douglas-fir forests of the Pacific Northwest," Forest Ecology and Management, vol. 145, no. 3, pp. 219-227, 2001.

[14] C. D. Oliver and B. C. Larson, Forest Stand Dynamics, Update Edition, John Wiley \& Sons, New York, NY, USA, 1996.

[15] K. U. Plauborg, "Analysis of radial growth responses to changes in stand density for four tree species," Forest Ecology and Management, vol. 188, no. 1-3, pp. 65-75, 2004.

[16] Western Regional Climate Center, "Historical Climate Information," 2010, http://www.wrcc.dri.edu/cgi-bin/cliMAIN .pl?ca2147.

[17] Natural Resources Conservation Service (NRCS), “Web Soil Survey," 2010, http://websoilsurvey.nrcs.usda.gov/.

[18] J. E. King, "Site index curves for Douglas-fir in the Pacific Northwest," Weyerhaeuser Forest Paper 8, Weyerhaeuser Forest, Centralia, Wash, USA, 1966.

[19] B. Krumland and L.C. Wensel, "Height growth patterns and fifty year base age site index curves for young growth coastal redwood," Co-Op Redwood Yield Research Project Research Note 4, University of California, Berkeley, Calif, USA, 1977.

[20] K. L. O'Hara, "Dynamics and stocking-level relationships of multi-aged ponderosa pine stands," Forest Science, vol. 42, no. 4, pp. 1-34, 1996, Monograph, vol. 33, pp. 34.

[21] L. M. Baker, M. Z. Peery, E. E. Burkett, S. W. Singer, D. L. Suddjian, and S. R. Beissinger, "Nesting habitat characteristics of the marbled murrelet in central California redwood forests," Journal of Wildlife Management, vol. 70, no. 4, pp. 939-946, 2006.

[22] R. V. Pelt and S. C. Sillett, "Crown development of coastal Pseudotsuga menziesii, including a conceptual model for tall conifers," Ecological Monographs, vol. 78, no. 2, pp. 283-311, 2008.

[23] C. R. Keyes, "Thinning promotes the restoration of branch structure in second-growth redwoods at Redwood National Park," Ecological Restoration, vol. 29, no. 4, pp. 325-327, 2011.

[24] D. A. Maguire, M. Moeur, and W. S. Bennett, "Models for describing basal diameter and vertical distribution of primary branches in young Douglas-fir," Forest Ecology and Management, vol. 63, no. 1, pp. 23-55, 1994.

[25] S. Hein, A. R. Weiskittel, and U. Kohnle, "Branch characteristics of widely spaced Douglas-fir in south-western Germany: comparisons of modelling approaches and geographic regions," Forest Ecology and Management, vol. 256, no. 5, pp. 1064-1079, 2008.

[26] N. Fahlvik, P. M. Ekö, and N. Pettersson, "Influence of precommercial thinning grade on branch diameter and crown ratio in Pinus sylvestris in southern Sweden," Scandinavian Journal of Forest Research, vol. 20, no. 3, pp. 243-251, 2005.
[27] H. Ishii and N. McDowell, "Age-related development of crown structure in coastal Douglas-fir trees," Forest Ecology and Management, vol. 169, no. 3, pp. 257-270, 2002.

[28] K. W. Cremer, C. J. Borough, F. H. McKinnell, and P. R. Carter, "Effects of stocking and thinning on wind damage in plantations," New Zealand Journal of Forest Science, vol. 12, pp. 244-268, 1982.

[29] H. T. Wonn and K. L. O'Hara, "Height:diameter ratios and stability relationships for four northern Rocky Mountain tree species," Western Journal of Applied Forestry, vol. 16, no. 2, pp. 87-94, 2001.

[30] M. J. Ducey and B. C. Larson, "Accounting for bias and uncertainty in nonlinear stand density indices," Forest Science, vol. 45, no. 3, pp. 452-457, 1999.

[31] B. Zeide, "How to measure stand density," Trees, vol. 19, no. 1, pp. 1-14, 2005.

[32] L. H. Reineke, "Perfecting a stand-density index for even-aged forests," Journal of Agricultural Research, vol. 46, pp. 627-638, 1933.

[33] A. J. Chittick and C. R. Keyes, "Holter Ridge thinning study, Redwood National Park: preliminary results of a 25-year retrospective," in Proceedings of the Redwood Region Forest Science Symposium: What Does the Future Hold? R. B. Standiford, G. A. Giusti, Y. Valachovic, W. J. Zielinski, and M. J. Furniss, Eds., USDA Forest Service General Technical Report PSW-GTR194, pp. 271-280, Pacific Southwest Research Station, Albany, Calif, USA, 2007.

[34] A. Hammon, H. Jensen, and A. Wallen, "Proposed Rellim Redwood Company allocation of the northern redwood purchase unit lands. Del Norte County, California," Timber Inventory Report, U.S. Department of the Interior by Hammon, Jensen, Wallen \& Associates, Inc., Oakland, Calif, USA, 1969.

[35] R. T. Busing and T. Fujimori, "Dynamics of composition and structure in an old Sequoia sempervirens forest," Journal of Vegetation Science, vol. 13, no. 6, pp. 785-792, 2002.

[36] G. A. Giusti, "Structural characteristics of an old-growth coast redwood stand in Mendocino County, California," in Proceedings of the Redwood Region Forest Science Symposium: What Does the Future Hold? R. B. Standiford, G. A. Giusti, Y. Valachovic, W. J. Zielinski, and M. J. Furniss, Eds., USDA Forest Service General Technical Report PSW-GTR-194, pp. 161-168, Pacific Southwest Research Station, Albany, Calif, USA, 2007.

[37] C. M. Dagley, "Spatial pattern of coast redwood in three alluvial flat old-growth forests in Northern California," Forest Science, vol. 54, no. 3, pp. 294-302, 2008.

[38] S. C. Sillett and R. Van Pelt, "Trunk reiteration promotes epiphytes and water storage in an old-growth redwood forest canopy," Ecological Monographs, vol. 77, no. 3, pp. 335-359, 2007.

[39] C. G. Lorimer, D. J. Porter, M. A. Madej et al., "Presettlement and modern disturbance regimes in coast redwood forests: implications for the conservation of old-growth stands," Forest Ecology and Management, vol. 258, no. 7, pp. 1038-1054, 2009.

[40] R. J. Stathers, T. P. Rollerson, and S. J. Mitchell, "Windthrow handbook for British Columbia forests," British Columbia Ministry of Forests Working Paper 9401, British Columbia Ministry of Forests, Victoria, Canada, 1994.

[41] H. Ishii and M. E. Wilson, "Crown structure of old-growth Douglas-fir in the western Cascade Range, Washington," Canadian Journal of Forest Research, vol. 31, no. 7, pp. 12501261, 2001.

[42] S. D. Roberts, C. A. Harrington, and K. R. Buermeyer, "Does variable-density thinning increase wind damage in conifer 
stands on the Olympic Peninsula?" Western Journal of Applied Forestry, vol. 22, no. 4, pp. 285-296, 2007.

[43] J. R. Teraoka and C. R. Keyes, "Low thinning as a forest restoration tool at Redwood National Park," Western Journal of Applied Forestry, vol. 26, no. 2, pp. 91-93, 2011.

[44] A. B. Carey, "Biocomplexity and restoration of biodiversity in temperate coniferous forest: Inducing spatial heterogeneity with variable-density thinning," Forestry, vol. 76, no. 2, pp. 127-136, 2003.

[45] A. B. Carey and C. A. Harrington, "Small mammals in young forests: implications for management for sustainability," Forest Ecology and Management, vol. 154, no. 1-2, pp. 289-309, 2001.

[46] C. R. Keyes, T. E. Perry, and J. F. Plummer, "Variable-density thinning for parks and reserves: an experimental case study at Humboldt Redwoods State Park, California," in Proceedings of the National Silviculture Workshop, USDA Forest Service Proceedings RMRS-P-61, pp. 227-237, 2010. 

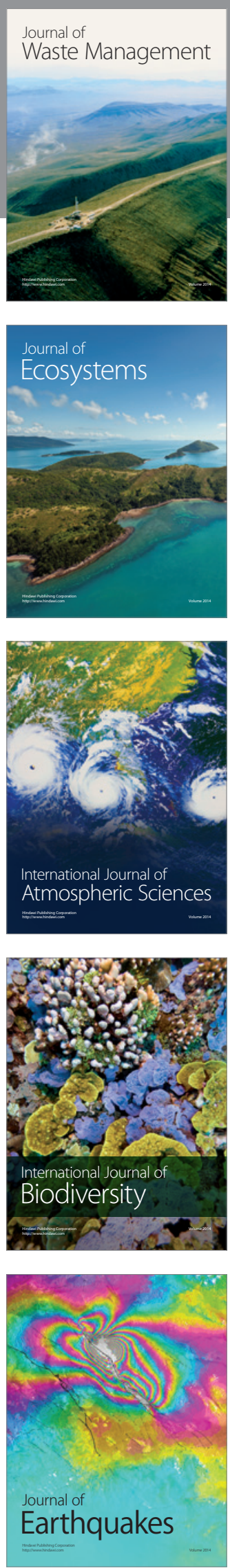
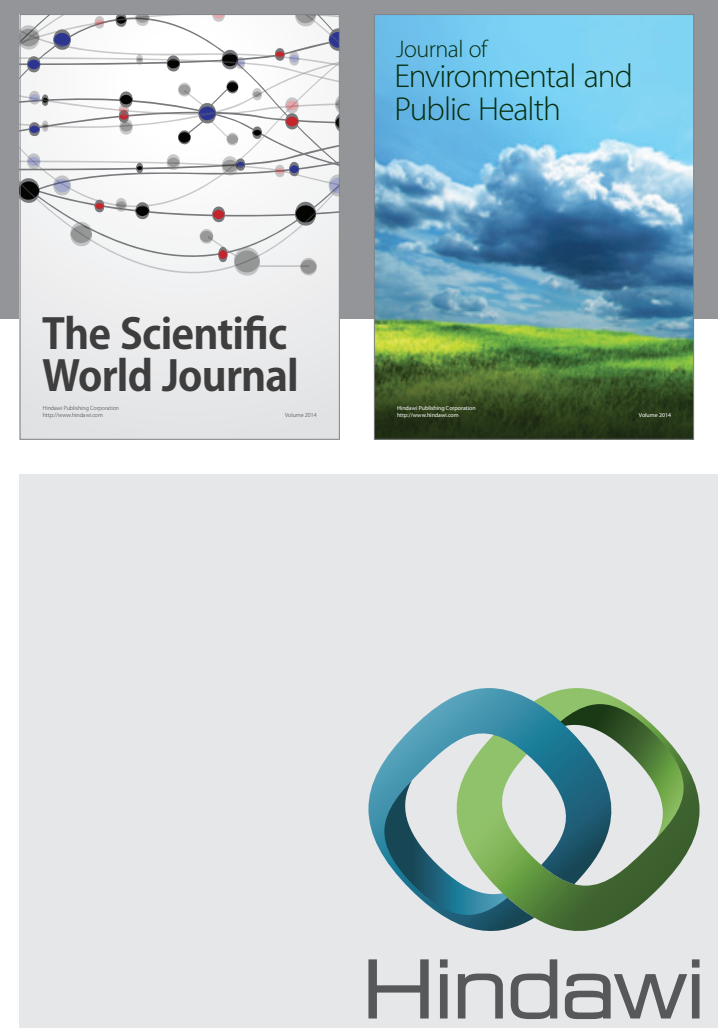

Submit your manuscripts at

http://www.hindawi.com
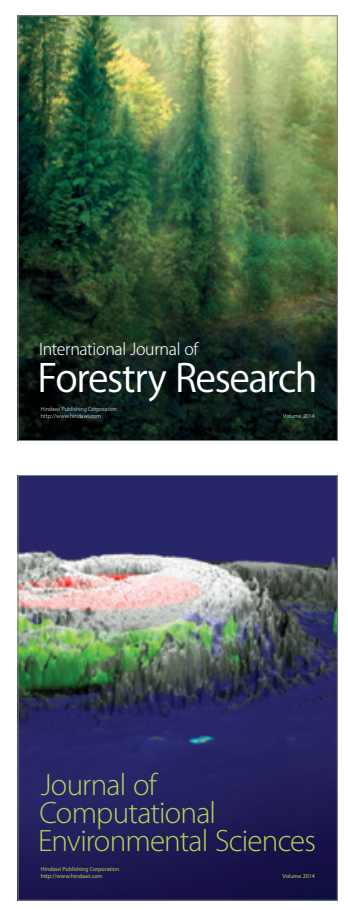
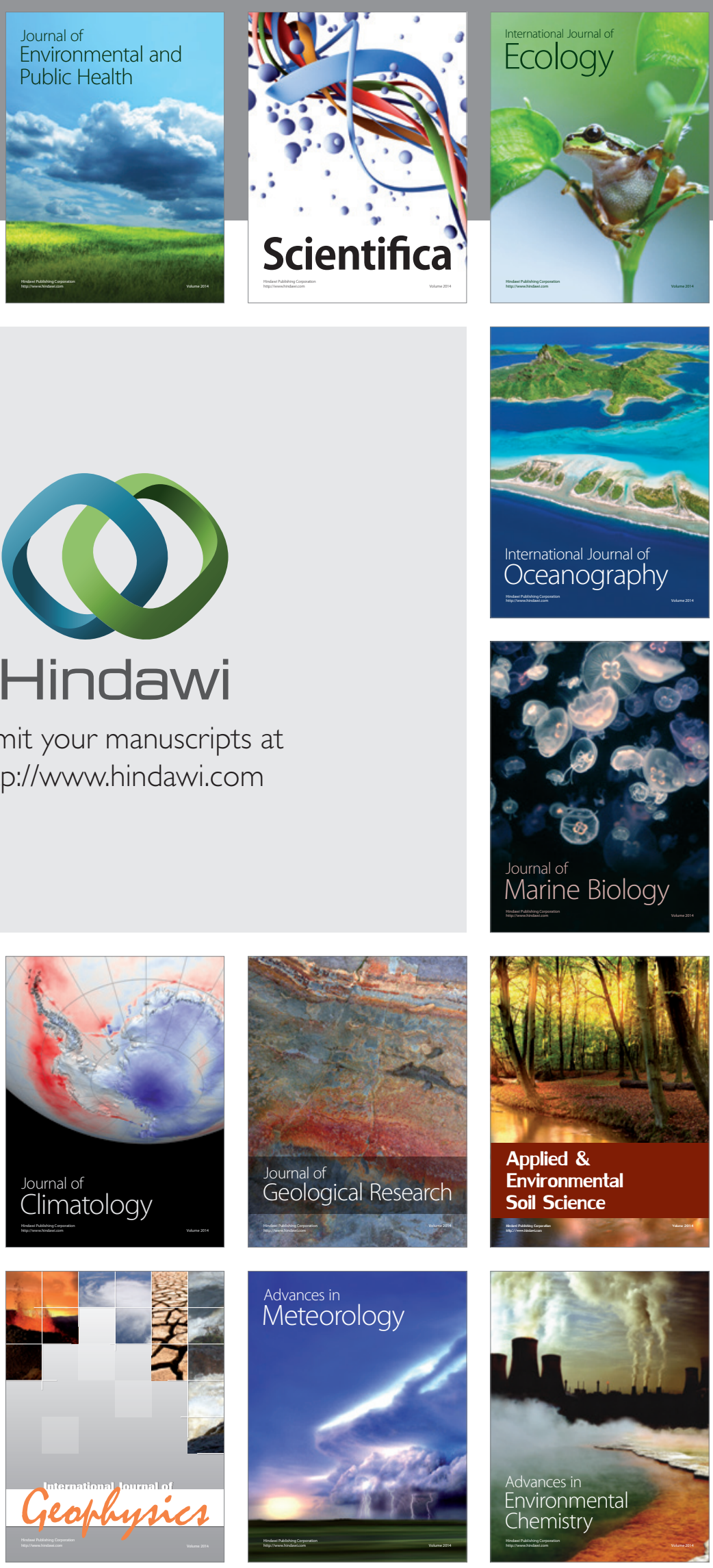